\title{
脳血管障害の発症部位別による日常生活上の困難と その支援方法の検討
}

\author{
河 原 加代子'1)，伊 藤 まゆみ² \\ 1) 群馬県立医療短期大学 \\ 2) 群馬大学医学部保健学科 \\ (平成11年 5 月12日 受付)
}

\begin{abstract}
要 旨：本研究の目的は, 脳血管障害の発症部位別による日常生活上の困難に焦点をあて, 在宅における 障害者及び家族の介護状況を把握し専門職による援助を検討することである. 対象は東京 M市に在住する脳 卒中の家族会に所属する介護者 10 名であり, 調査方法は面接調査を実施した. 結果として,

1）脳血管障害による機能障害・能力障害は, 日常生活に現れる現象を発症部位で分類することにより,
（1）前頭葉症状：「自発性の低下」
(2) 左半球症状:「失語」「失行」
(3) 右半球症状:「左半側空間無

視」「失認」等の機能障害に対する共通した対処方法を抽出することができる.

2）在宅という環境では, 脳血管障害者及び介護者の直面する困難を日常生活行為という単位でとらえる

ことで, 介護者の対処のしかたをより具体的に把握することができる.

以上のことから, 脳血管障害者及び介護者への支援は, この疾患特有の機能障害, 特に高次脳機能障害から 生じる生活上の混乱や困難に対する十分な説明と日常生活場面における具体的な対処方法を指導することが 重要である.
\end{abstract}

Key words：脳血管障害, 日常生活行為, 家族介護者

(Kitakanto Med.J. 49 (4) : 261 268, 1999)

Iはじめに

脳血管疾患による死亡率は, 1970 年の 175.8 (人口 10 万対）をピークに大きく減少したものの，その受療率は 依然として高い1)。また脳血管疾患は，通院者の主傷病別 にみた日常生活に影響のある疾患の高血圧症に次ぐ第 2 位となっており ${ }^{21}$, 急性期の集中治療とリハビリテー ションを経た後も, 何らかの機能障害を残し, 退院後の 在宅介護を必要とすることが少なくない.

このような在宅療養に移行した脳卒中後遺症をもつ障 害者 87 名を対象に公的機関による機能訓練やデイケア の場における「活動」(社会的相互作用) が有効であるこ とを報告した調査 ${ }^{3)}$ に引き続き, 87 名の障害者の中から 面接可能な者 30 名を対象とした面接調査を実施して, 脳血管障害者の障害の受容には家族との関わりが大きく 影響してことを明らかにした ${ }^{4)}$.そして同時に，障害者を 含めた家族 (特に主介護者) 全体を援助していく必要性 が示唆された。
脳血管疾患は, その症状の複雑さ, 機能障害のレベル とその改善の程度は個々に異なるが, 発症部位により, その機能障害にかなり違いがあることがわかっている5 本研究はそのような脳血管障害の発症部位別による日常 生活上の困難の特徵を明らかにし, 在宅における障害者 及び家族の介護状況の実態と専門職の効果的な援助を検 討することである.

\section{II 対象及び方法}

\section{1 対象者}

東京M市に在住する脳血管障害者を介護する家族会に 所属している介護者 87 名の中から以下の基準に該当す る者のうち, 13 名に協力を依頼し 10 名より承諾を得た。

1）脳血管疾患の最初の発作による機能障害が出現し た障害者の介護を現在継続している者. なお，障害 者の初発年齢は, 障害者の年齢により公的サービス の利用条件が異なるため 40 代から 60 代の幅で選出 する. 
2）退院後の在宅介護の経験がはじめてであった者.

3）介護者の介護する脳血管障害者は，発症部位によ り，その機能障害にかなり違いがあるため発症部位 に偏りがないよう選出する，少なくとも，前頭葉症 状, 左半球症状, 右半球症状，大脳基底核～内包，視 床, 小脳, 脳幹等の部位など.

4）介護役割をとる人間が，性別や立場によって，そ の介護状況や介護負担も異なってくることが予想さ れるため, 介護者が夫, 妻, 同居の子供とその配偶者 など偏りがないように選出する.

\section{2 調査期間}

1997 年 9 月～10月.

\section{3 調査方法}

データ収集は家庭訪問による面接調査を実施した。 データ分析は, テープに録音した内容を以下の視点で 行った. (1) 日常生活場面において, 障害者及び介護者の 行動あるいは活動を選出する. (2) その行動を構成して いる諸活動を運動の階層性, すなわち運動 (movement), 動作 (motion), 行為 (act,conduct) ${ }^{6)}$ から分析する. (3) 脳 血管障害者の障害を, 発症部位別に分類し, 介護者の対 処のしかたと専門職の効果的な援助を検討する.

\section{III結果及び考察}

\section{1 対象者の属性}

表 1 は, 介護者と障害者の現在の年歯, 発症時の年齢, 障害者の病名と主な障害名, そして介護役割を担う介護 者の立場を示したものである.介護役割をとる人間は, 女性 7 名, 男性 3 名で，妻である場合が最も多く（5 事 例), 次いで夫 (3 事例), 娘 (既婚) と娘 (未婚) が各 1 事例 ずつであった. 今回の調査では嫁の立場をとる事例は得 られなかった. また介護者の年齢は, 発症当時 30 代から 60 代にほぼ偏りがなかった. 障害者は, 男性 5 名, 女性 5 名であり，年齢は 40 代から 60 代にわたっている. 発症 してから現在に至るまでの療養期間については, 最も短
くて 3 年, 最も長い事例では 19 年とばらつきがあった.

\section{2 発症部位別にみた機能障害より生じる日常生活場面}

\section{における困難と介護者の対応}

脳血管障害の中でも最も困難の大きいと思われる高次 脳機能障害の事例を取り上げ, 障害者および介護者が日 常生活場面で直面する困難とそれに対する介護者の対応 を示した。

なお，日常生活場面は，「食事」「排泄」「入浴」「更衣」

「整容」「健康管理」「余暇活動」「コミュニケーション」 の各行為レベルで分析し, 介護者の言葉を引用, その対 処のしかたを検討した. 行為のレベルで分析しにくい場 合は動作として分析した.「移動」は動作として扱った.

1 ) 前頭葉症状を呈する障害者の日常生活上の困難と その対処

表 2 は，同じ前頭葉症状であっても現象の全く異なる 2 事例を取り上げ, 直面する日常生活の困難を示したも のである.

（1）事例 5 女性 (発症時年齢：54 歳) $\lceil$ く膜下出血」

〈機能障害〉前頭葉症状, 廃用性症状重度, 右片麻㽻, 運 動失調

〈現病歴〉1988 年 12 月, くも膜下出血にて某病院にて手 術施行 (L.P シャント術 1 回目). 1989 年 8 月, リハビリ のために転院する. 1990 年 2 月にシャントが詰まり, 2 回目の手術施行. 1992 年 5 月, さらにシャントが詰まり, 3 回目の手術施行. その後はシャントの機能良好にて, 同 年 6 月に自宅退院となる.

〈退院時 ADL〉前頭葉症状により, 自発性低下重度で, 無 表情. 自発語もほとんどない. 生活行為は全介助を要し た. 排泄はおむつ使用.

〈生活歴〉華道の師匠で, 多くのお弟子をかかえていた. 〈住宅状況〉持ち家.

表 1 障害者・介護者一覧

\begin{tabular}{|c|c|c|c|c|c|c|c|c|c|}
\hline 事例 & 性別 & 年齢 & \begin{tabular}{|l|} 
発症時 \\
年 齢
\end{tabular} & 名 & 主 な 障 害 名 & 介護者 & 性別 & 年齢 & 発症時年齢 \\
\hline 1 & 男性 & 65 & 62 & 脳 出 血 & 左半球症状, 失語・失行, 右片麻痺, 運動失調 & 妻 & 女性 & 63 & 60 \\
\hline 2 & 女性 & 64 & 60 & 脸 梗 & 脳幹部, 右片麻痺, 構音障害, 嬩下障害 & 夫 & 男性 & 69 & 65 \\
\hline 3 & 男性 & 62 & 54 & 脳 梗 塞 & 左半側空間無視, 左半側身体失認, 運動失調 & 妻 & 女性 & 50 代 & 40 代後半 \\
\hline 4 & 女性 & 61 & 53 & 脸 出 血 & $\begin{array}{l}\text { 多発性, 左片麻痺, 左感覚麻痺, 右運動麻痺 } \\
\text { (軽度) }\end{array}$ & 夫 & 男性 & 72 & 64 \\
\hline 5 & 女性 & 62 & 54 & くも膜下出血 & $\begin{array}{l}\text { 前頭葉症状, 右片麻痹, 廃用性症状重度, 運動 } \\
\text { 棹 }\end{array}$ & 夫 & 男性 & 68 & 59 \\
\hline 6 & 女性 & 74 & 69 & 脳出 & 左片麻痺 & 娘(既婚) & 女性 & 40 代 & 30 代後半 \\
\hline 7 & 男性 & 56 & 53 & 脳 出 血 & 左半球症状, 失語- 失行, 右片麻瘴, 運動障害 & 妻 & 女性 & 52 & 49 \\
\hline 8 & 男性 & 63 & 59 & くも膜下出血 & 前頭葉症状 & 妻 & 女性 & 59 & 55 \\
\hline 9 & 男性 & 67 & 48 & 脳出 & 左片麻痺 & 妻 & 女性 & 60代 & 40代 \\
\hline 10 & 女性 & 74 & 69 & 脳 虚 & 四肢麻痺 & 娘(未婚) & 女性 & 42 & 37 \\
\hline
\end{tabular}


表 2 前頭葉症状

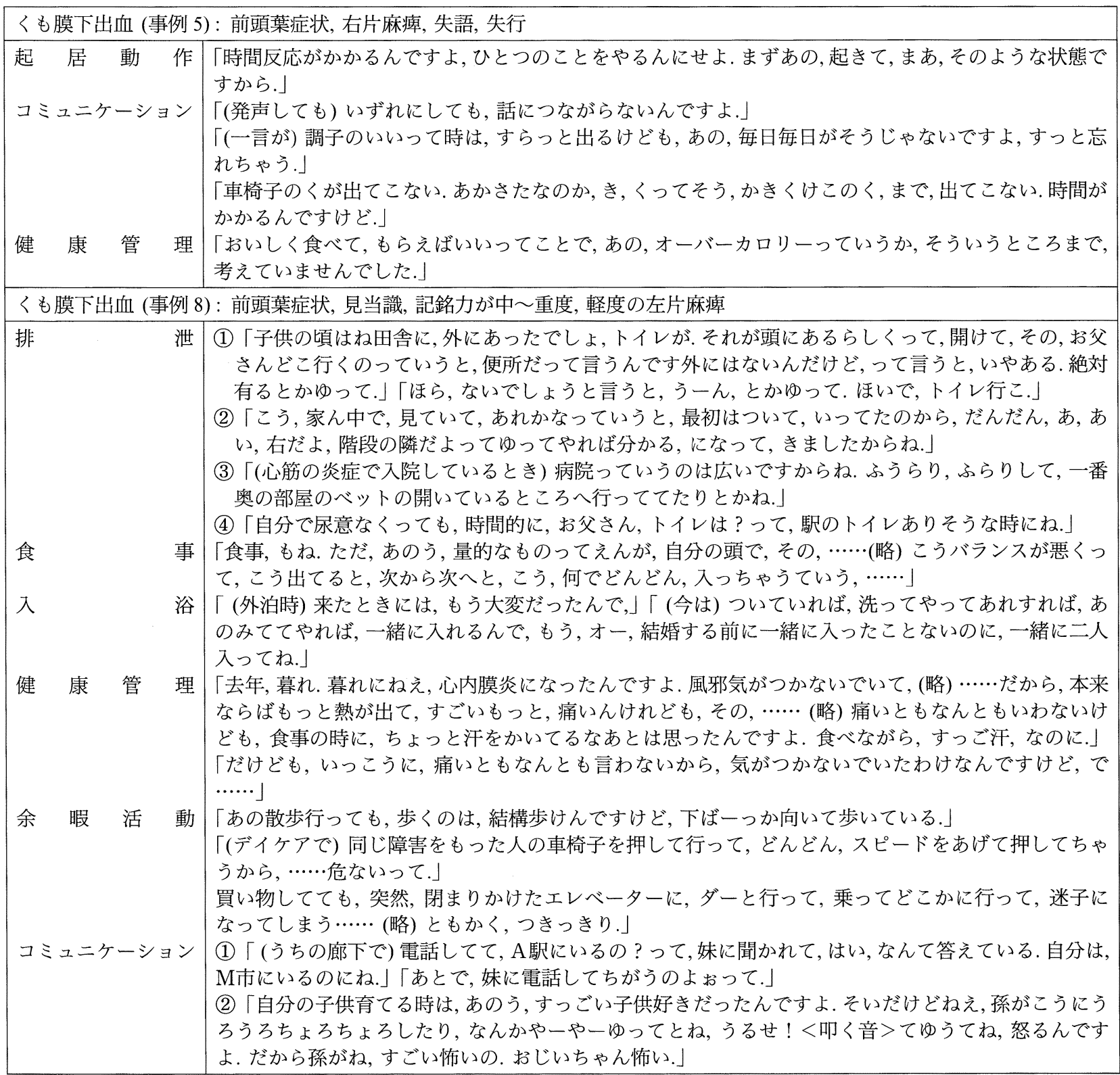

\section{日常生活上の困難と关の対処の過程}

事例 5 において, 介護者が最も困難を感じたことは, 障害者がすべての動作を自発的に行うことができないこ とであった. 介護者が動作をうながそうとする関わり， すなわち「コミュニケーション行為」が成り立たないこ とであった. 高次脳機能障害を呈する前頭葉症状の損傷 の特徵の 1 つに, この自発性の低下がある.この事例で は自発性の低下が重度であり, 全く自ら動こうとしない ため, 介護者は 24 時間つきっきりで, 体位交換をはじめ, 日常生活行為全体にわたり, 全介助で介護を必要として いた. また発語がほとんどないため,「痛い」等の訴えも なかった. 試行錯誤の介護を繰り返す時間の経過ととも に少しずつ改善してきた事例であった. 介護者は, 生活 行為の中で, 常に声かけをしたり, 周囲から誘導したり, 動作のたびに繰り返し説明し, 実に根気よく関わりを続
けていた.

「食事を摂る」という生活行為に関しては, 介護者はい ろいろ工夫を重ねていたが，自発性の低下が重度のこの 事例では, 障害者自ら食事を選択したり, 量を加減した りできないため介助されるまま出されるままに搨取して いた. そのため, 体重増加や糖尿病の悪化が指摘される 等の「健康管理」面での問題が生じた. すべてにおいて自 発的に訴えがないため, 他者による観察や注意が不可欠 であることが問題とされた。

（2）事例 8 男性 (発症時年齢：59 歳)

$\lceil<も$ 膜下出血」

〈機能障害〉前頭葉症状, 見当識, 記銘力が中〜重度, 軽 度の左片麻痺

〈現病歴〉1992 年 11 月，〈も膜下出血にて某病院に入 院. 手術施行 (術式不明). 2ヶ月経過の後, リハビリのた 
めに転院. さらに4ヶ月間,リハビリを行って自宅退院と なる.

〈退院時 ADL〉見当識, 記銘力が中〜重度, 軽度の左片麻 痺が残る. 排泄はトイレへの誘導, 介助を要した. 歩行は 可. 作話, 病室の間違い, 徘䧃がみられた.

〈生活歴〉公務員時代に茶道, バトミントンなどの趣味 あり。

〈住宅状況〉持ち家.

\section{日常生活上の困難と光の対処の過程}

同じ前頭葉症状の場合でも，事例 8 の場合は，自発性 低下の症状が改善傾向にあった事例であった. 表 2 亿示 すように，障害者の運動麻痺は軽くても，前頭葉症状の 特徵である見当識障害, 記銘力の改善が停滞している時 期は, 麻痺が軽いため, 障害者本人の突発的な行為が混 乱や危険を招く場合があった.この事例では,「排泄行為」 で，障害者がトイレが戸外にあるという子供の頃の記憶 に固執して主張するため, トイレを探して庭をうろうろ するといった現象がしばしばみられた，そのような場面 に直面した介護者や家族は，間違っていることを指摘し てトイレの場所へ連れていったが, 否定されると感情が コントロールできずに障害者がさらに混乱し暴れると いったことが生じた. 数年間, 介護を継続する過程で, こ のような場合は，まず介護者も障害者と一緒に庭を見に 行き, 障害者とともに,「ほら,ないでしょう?」といって 事実を確認しながら，障害者の思っていることを自己修 正できるように促す対応を行っていた. 介護者が障害者 の行動を見守り，「右だよ，階段の隣だよ」と声かけて行 動できるように誘導するとできる行為もみられた：この 事例では, 介護者が実に根気よく愛情をもったかかわり を長期に継続していた.

「食事行為」では, この事例はたびたび食物を詰め込み すぎてロからこぼした：そのため普通のペースで食べら れるようになるのに数ヶ月以上かかった．この事例では, 障害者一人で適度な早さで食べたり, 適度な量を食べる までに改善していないため，家族が協力して食事をする ようにして対応していた，家族と一緒に食事をすること は食べる楽しみを感じる機会の提供にもなるため,こう した対応は適切であると考えられた

次に「入浴」であるが, 表 $2\lceil 入$ 入浴」の介護者の言葉の

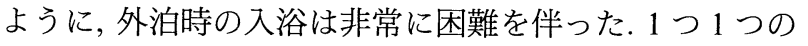
行為に, 注意・判断力が低下しており, 目がはなせない状 態であった. 退院してからの介助は, 前頭葉症状の改善 とともに, 一緒に入浴することで排泄の場合と同様, 声 かけをして自己修正を促す対応が可能になっていた．

「健康管理」とは，疾患の!スク管理，二次障害の予防
そして健康全般にわたる管理を含む，この事例では，風 邪から心内膜炎を引き起こしたが, 心内膜炎という診断 が下されるまで半月も要した. 軽度の運動麻痺があり, 同時に感覚障害を伴っているため, 自覚症状の訴えが少 ない.こうした障害者は, 介護者が気づかなければ, 放置 されたままの状態でいることもしばしばみられた。医療 機関にかかった場合には，日頃の様子などを詳細に話し， はじめての医師でも障害を考慮した判断が可能なような 情報提供が必要である.

「余暇活動」は, 活動を展開するための「移動」動作か らそれに関連する活動自体を含む. 前頭葉症状の特徵は, 事例 8 のように「自発性の低下」の改善がみら机ると, 病 識・注意力が低いままに思いつきの行動をとることがし ばしばみられた．障害者自身は自分のことを障害がある と思っていないため, 発症以前に役所で車の運転をして いたことが記憶にあるためか, この事例は車椅子の障害 者をみるとその世話をする行動をとっていた．しかし適 切な速さで車椅子を押すなどの対応はできないため, 突 発的に急なスピードで車椅子を押してしまい，障害者自 身にとっても，また車椅子に座している障害者にとって も危険な場面がみられた，事例 8 は, 麻痺は軽度であっ ても「生活行為」のレベルで行動に危険があり，常に目が 離せない状態が現在も続いていた. 介護者は, 1 つ 1 つの 生活行為のレベルで, 声をかけ見守り, 必要時に手振り で指示したり，自己修正を促すといった介護を継続する 必要が続いていた。

前頭葉症状を呈する障害者に対応する者が最も混乱を 来すのが,「コミュニケーション行為」である. 事例 8 よ うに記憶障害一作話があると，日付や場所の区別が定か ではなくなる．しかし過去の記憶や常識は備わっている 場合が多い，そのため，はじめて電話で話すような場合 は，その応対は障害者と話をしているとは全く感じさせ ない対応をした．また顔を合わせていても，その場限り の内容については，ちぐはぐな会話にならないため「作 話」に気づかない場合もあった.また, 前頭葉症状の「人 格障害」として一般的に指摘されているふざけ症や易怒 性がみられたこの事例では，それらが病気による障害の 影響であることを周囲の者が理解しておくとともにトラ ブルを生じないような環境づくりが必要である.

以上のことから, 前頭葉症状を呈する障害者の日常生 活上の困難は，廃用性症状が重度であり「自発性の低下」 が顕著な場合は, 生活行為すべてにわたり全介助を必要 とする場合が多い.さらに自発的な訴えがないため, 生 活行為 1 つ 1 つに常に声かけをしたり, 周囲から誘導し たり,動作・行為のたびに繰り返し説明することが必要 となる.同じ前頭葉症状であっても、「見当識障害」「記銘 
表 3 左半球症状

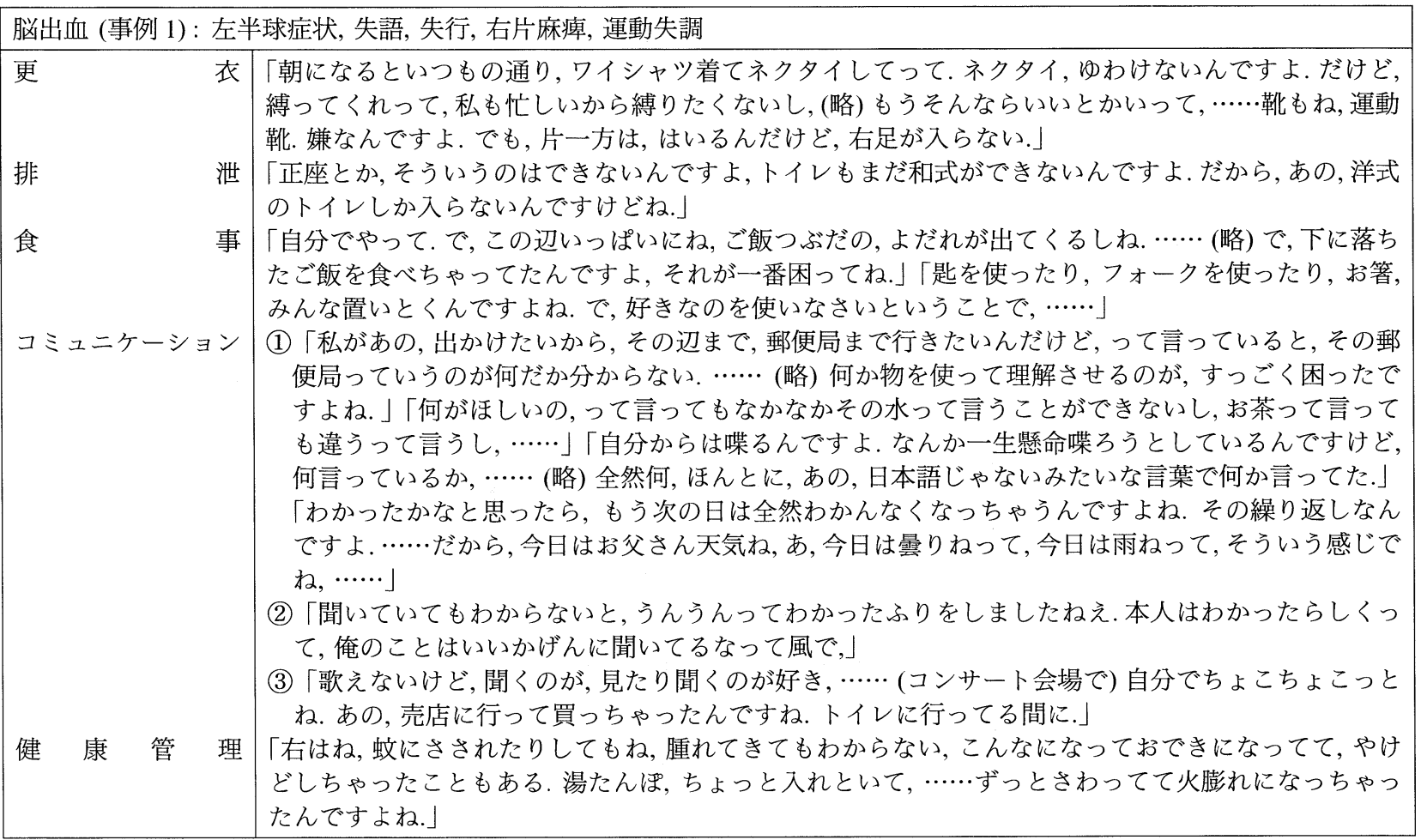

力低下」が重度であるが, 麻痺による運動機能の低下は 軽度である場合は, 生活行為の身体的な介助は必要とし なくても，障害者の突発的な行為が周囲の人間に混乱や 危険を招くおそれがある. 障害者の間違った行為をすぐ に否定するのではなく, 障害者の思っていることを自己 修正できるように促す対応を根気よく繰り返すことが重 要である.

2 ）左半球症状を呈する障害者の日常生活上の困難と その対処

表 3 は, 発症部位が左半球に生じた事例である.

事例 1 男性 (発症時年齢：52 歳) 「脳出血」

〈機能障害〉左半球症状, 失語・失行, 右片麻痺, 運動失 調

〈現病歴〉1993 年 6 月, 脳出血にて某病院入院. 2ヶ月治 療経過をたどり転院. 8ヶ月間リハビリを行って自宅退 院となる。

〈退院時 ADL〉失語重度, 失行, 右片麻痺にて歩行は軽介 助から監視が必要. 見当識, 記銘力障害が中程度あり.

〈生活歴〉公務員を退職前に辞職し，事業を起こしてい た.

〈住宅状況〉持ち家.

\section{日常生活上の困難とその対処の過程}

「更衣」の場面では, 長年公務員として働いてきた経緯
をもつ障害者には，人と会う時はネクタイをしてきちん とした格好で外出したいという願いがあった.リハビリ の訓練で外出することは, 障害者にとっては人と対面す る社交の場であった. 介護者が簡単に脱ぎ着できるト レーナーやカーディガンを進めても, 頑として受けつけ ず，ワイシャツにネクタイをしたい意志を通した. 結局, どうしても獲得できない動作 (ネクタイを結ぶ等) から 獲得している動作 (ループタイならかけられる) を利用 して,ワイシャツを着て外出したいという「生活行為」の 自立を獲得した。

同様に「排泄」という生活行為の自立には, 正座ができ なくても，洋式トイレに改造することで目的を達成する ことが可能になった.

次に「食事行為」であるが, 表 3 「食事」に示すように, 障害者が食物を口に運ぶ道具の名称を言えない代わりに 匙やフォーク，箸を並べて選ばせるようにした介護者の 対応は, 介護者が「失行」という障害について十分把握で きていなかったため, やむを得ずとった行動であった. 「失行」のある場合, 何かものを使ったり模倣を中心と した関わりは, 非常に困難である.「失語」を単に話すこ とができないだけの障害と判断すると, こうした模倣が 効果的であると考えがちである傾向が指摘された.

さらに,「コミュニケーション行為」に関わる困難は最 も大きかった. 特に高次脳機能障害については, 毎日の

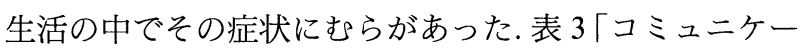
ション」行為で介護者が障害者の症状を毎日の天気の変 
化に例えて説明しているように，1)介護者があせらず， 気長に対応していくゆとりが必要である。また(2)のよう に，とりがない時やどうしてもわからない場合に，わ かったふりをしてしまいがちである.しかし，あとでト ラブルのもとになるため，わからなかったことを伝える 努力が必要である.ささに, (3)徐々に改善していく過程 にあっても, 判断力などの高度な能力に関しては, どの くらい回復しているか不確かな場合が多いので, 介護す る側の注意が必要であった。

高次脳機能障害は, たいていの場合, 片麻痺を伴って いる場合が多い.「健康管理」の面では, 麻痺側に共通し て注意を要する二次障害の予防が重要である. 特に事例 のように，自覚症状を訴える能力が低下している場合は 危険を察知するのが困難であるため, 十分な注意が必要 である。

以上のことから, 左半球症状を呈する障害者の日常生 活上の困難は, 「失語」や「失行」がある場合, 単に言葉 が話せないといった言語障害ではないため, 何かものを 使ったり模倣を中心とした対応の仕方は障害者に混乱を 招く場合がある．言語によるコミュニケーションの機能 回復には長期にわたるリハビリテーションを必要とする が, 毎日の生活行為の中で, あせらず, ゆっくり, 根気よ く繰り返して関わり続けることが重要であり, そのよう な対応がコミュニケーション能力の回復に最も重要とな る.

3 ）右半球症状を呈する障害者の日常生活上の困難と その対処

表 4 は, 発症部位が右半球に生じた事例である。

事例 3 男性 (発症時年歯：54 歳) $\lceil$ 脳梗塞」

〈機能障害〉右半球症状, 左半側空間無視, 左半側身体失 認, 運動失調

〈現病歴〉1988 年, 仕事先で脳梗塞で倒れ入院. 3ケ月治 療経過をみて, 転院. $\mathrm{A}$ 病院, B病院と転院し 13ヶ月あま
りリハビリを行い, 自宅退院となる.

〈退院時 ADL〉車椅子使用で移動動作を行う. 歩行は杖 を使用し, 介助があれば室内歩行は可能.

〈生活歴〉やり手の商社マンで, 海外を飛び歩く生活を していた。

〈住宅状況〉持ち家.

\section{日常生活上の困難と裹対処の過程}

表 4 に示すとおり, 右半球症状の代表的な「失認」や 「左半側空間無視」の症状を合併していた事例である. 自分の障害に対する認識が欠けるため, できると思い込 んで行動することが原因で起こる事故も多かった.

「食事行為」に関しては, 食べこぼしが多く, 衣服, 床 の污染があっても拾おうとしないというような現象がみ られた．お膳の左半分を見落とし食べ残した．そのため 湯などの注ぎ方などに注意できず，物品を落としたり， やけどなどの事故につながる危険性もあった．この事例 では，介護者が火をつかって温めたりなどの作業を入れ なかったことは，障害者一人で食事をとる環境であるの で大変重要なことであった.

「コミュニケーション行為」では, 表 4 の訴えのごとく, 「病識失認」すなわち, 障害者自身に病識がないため, ま わりにとって問題があると思える行動であっても，障害 者はそのように認識していないことがたびたび患者一介 護者間に混乱を引き起こした．さらに介護者が注意をう ながしても重要なことと受け止めて聞かないため, なか なか指示が実施されない，すぐ忘れるといった現象が起 きた. 介護者は, 障害者に関わる度に, どのように認識し てとった行動であるかを確認し，その都度，障害者が問 題を認識できるよう, 繰り返し関わっていた.

「排泄行為」については，この事例の失認では尿意に対 する認識の問題による失禁ではないため, 入院中から介 護者がオムツを除去し, ベット上排泄はなんとか可能に なっていた，しかし離床が可能になった時点より，病識

表 4 右半球症状

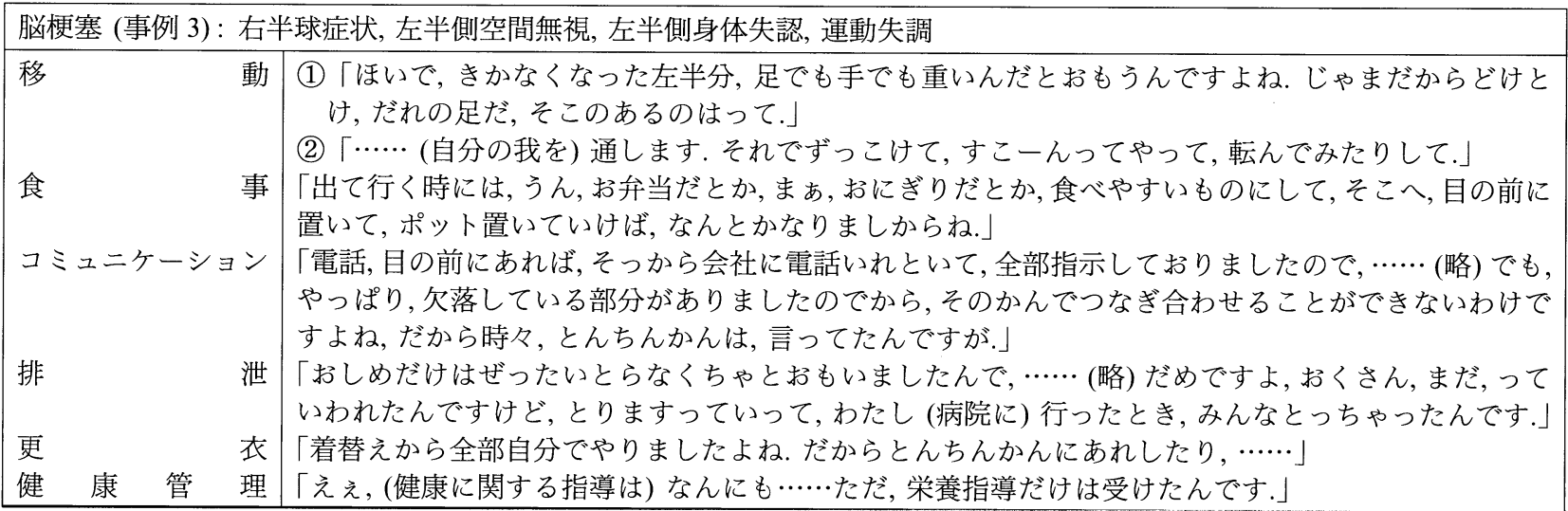


がないため, 左半側の身体をドアにぶつけたり,トイレ にいくために転倒する等の障害特有の動作に伴う危険が 常にあった。

「更衣」については, 服の表裏, 上下と身体の関係が混 乱し着替えができないという現象が起きた.そのときは， ゆったりとした着やすい服を選んだり，袖口や襟などに 目印となるボタンや糸印等をつける等の工夫をした。こ の事例の場合，介護者が排泄の自立と移動動作の自立に 対して強い願いがあり，その他の生活行為は援助するれ ばよいと考えていたが，障害の特徴をよく理解すること で, 他の行為の自立の可能性も検討される必要がある。

「健康管理」に含まれる疾病の管理という意味で, 服薬 指導は重要なことはいうまでもない. 失認という障害が 原因で起きる二次的なけがや事故などについても，十分 注意することが重要である.

以上のことから, 右半球症状を呈する障害者の日常生 活上の困難は, 「左半側空間無視」に対しては, 車椅子や 歩行等の移動時に障害者の視野に物体が入るように配置 したり，環境を整えることが必要となる．また「病識失 認」に対しては，障害者の訴えを介護者は受け止められ ず，介護者の説明を障害者が理解できないために言い争 うような事態が生じ易いので，障害者の行為をよく観察 し，障害者がどのように認識してとった行為であるかを 確認することが重要である.そしてその都度, 障害者が 問題を認識できるよう, 繰り返し対応していく必要があ る.

\section{IV 結 論}

在宅における脳血管障害者及び家族の介護状況の実態 を把握し，専門職の効果的な援助を検討するために，脳 血管障害の発症部位別による日常生活上の困難とその対 処に関する調査を実施し, 以下の点が明らかになった。

1. 脳血管障害による機能障害・能力障害は, 同じ脳血管 障害者であっても個々に異なり, その回復過程も様々 であるが，日常生活に現れる現象を発症部位で分類す ることにより，共通の対処方法を抽出することができ る.

1 ）前頭葉症状：「自発性の低下」が重度な場合は, 生活行為 1 つ 1 つに常に声かけをしたり, 周囲か ら誘導したり，動作のたびに繰り返し説明する. すべてにおいて自発的な訴えがないため, 介護者 の観察や注意が非常に重要となる．また「自発性
の低下」が改善されても「見当識障害」「記銘力低 下」が重度な場合は，障害者の突発的な行為が周 囲の人間に混乱や危険を招く恐れがある．障害者 の間違った行為をすぐ否定するのではなく，障害 者の思っていることを自己修正できるように促す 対応を根気よく繰り返すことが重要である.

2 ) 左半球症状:「失語」「失行」に対しては, 模倣を 中心とした関わりは困難であるため, ゆっくり， 根気よく繰り返し言葉をかけて対応することが重 要となる.

3 ) 右半球症状:「左半側空間無視」「病識失認」に 対しては，障害者がどのように認識してとった行 為であるかを確認し，その都度，障害者が問題を 認識できるよう, 繰り返し関わることが重要とな る.

2. 在宅という環境では, 脳血管障害者及び介護者の直 面する困難を日常生活行為という単位で分析すること で，介護者の対処のしかたをより具体的に把握するこ とができる.

3. 脳血管障害とその介護に特徵的にいえる困難は，在 宅における日常生活行為の困難というレベルでより顕 著な現象として現れるため, 脳血管疾患という疾患特 有の機能障害, 特に高次脳機能障害から生じる生活上 の混乱や困難に対する十分な説明と日常生活場面にお ける具体的な対処方法を指導することが重要である.

\section{V 文献}

1）厚生統計協会：国民衛生の動向，厚生の指標 臨時 増刊 45. 厚生統計協会, 1998.

2）平成 7 年国民生活基礎調査, 第 2 巻, 全国編, 厚生統 計協会, 平成 8 年.

3）河原加代子, 飯田澄美子：在宅療養に移行した脳卒 中後遺症をもつ患者の主観的満足感と活動の関連. 日看科会誌 $1996 ； 16(3) ： 40-47$.

4）河原加代子, 飯田澄美子：在宅脳血管障害者の障害 に対する受け止め方とその取り組みのプロセス. 保 健の科学 $1997 ; 39: 220-225$.

5）長谷川幹 (編) : 脳卒中者のリハビリテーション (第 2 版). 東京：日本医事新報社, 1995：9-21.

6）中村隆一 (編)：入門リハビリテーション概論 (第 2 版). 東京: 医歯薬出版, 1996：38-40. 
河原, 伊藤

\title{
DIFFICULTIES IN DAILY LIVING IN RELATION TO LESIONS AND TYPES OF ASSISTANCE NEEDED FOR PATIENTS OF CEREBROVASCULAR DISEASES
}

\author{
Kayoko Kawahara, Mayumi Ito \\ Gunma Prefectural College of Health Science \\ School of Health Sciences, Faculty of Medicine, Gunma University
}

The purpose of this study was to find types of professional assistance needed by focusing on difficulties in daily living in relation to lesions of cerebrovascular diseases and by understanding the types of care given to disabled persons and their families at home. Ten care givers who belong to Stroke Support Groups in M City, Tokyo were interviewed. Classifying difficulties in daily living by the impairment and disability associated with cerebrovascular lesions allowed us to identify types of assistance the patients need. The classification included : 1) frontal lobe symptoms, declining spontaneity and memory disorders and related fabulation; 2) left hemisphere symptoms, aphasia and cognitive disorders; and 3) right hemisphere symptoms, left unilateral spatial neglect and agnosia. In home environment we have to view the difficulties the patients of cerebrovascular diseases and their families encounter from the perspective of daily living activities so that we can obtain more specific and concrete ideas on how they can be supported.

It can be concluded that the cerebrovascular patients and their families need sufficient information concerning challenges and difficulties in daily living caused by the impairment specific to the disease, especially by the impairment of higher brain. It is also necessary to provide specific instruction on how their daily living should be adapted.

Key words : Cerebrovascular Diseases, Activities of Daily Living, Family Caregiver 